\title{
ОРГАНІЗАЦІЯ МОНІТОРИНГУ ТА ПРОГНОЗУВАННЯ РОЗВИТКУ РЕГІОНАЛЬНИХ СИСТЕМ ВИЩОЇ ОСВІТИ
}

\author{
Оксана Ломоносова \\ ОРГАНИЗАЦИЯ МОНИТОРИНГА И ПРОГНОЗИРОВАНИЯ РАЗВИТИЯ \\ РЕГИОНАЛЬНЫХ СИСТЕМ ВЫСШЕГО ОБРАЗОВАНИЯ
}

\author{
Oksana Lomonosova \\ ORGANIZATION OF MONITORING AND FORECASTING OF REGIONAL \\ HIGHER EDUCATION SYSTEMS DEVELOPMENT
}

У статті обтрунтована необхідність забезпечення основних стейкхолдерів вищої освіти об'єктивною інформацією про стан і розвиток регіональної вищої школи, щяо має важливе значення для підвищення обтрунтування управлінських рішень, які приймаються. Це вимагає організаиії безперервного моніторингу та прогнозування змін регіональних ринків освітніх послуг вищзої освіти. Комплекс досліджень повинний включати аналіз, оцінку та прогнозування процесів, ще відбуваються у вищій освіті регіону, а також на ринку прачі. Показано, щьо організація дієвого моніторингу можлива лише за умов тісної взаємодії регіональних закладів вищої освіти, органів державної влади й місиевого самоврядування. Роль останніх полягає у визначенні напрямів розвитку регіонального ринку прачі та прогнозуванні змін на ньому. На прикладі Херсонської області показано, щзо можливою організаційною формою, яка дає змогу виконувати необхідні дослідження, може бути науково-дослідний центр моніторингу, щю створюсться при органах державної влади.

Ключові слова: економіка знань; людський капітал; підготовка кадрів; регіон; вища освіта; моніторинг вищої освіти; прогнозування вищої освіти.

Табл.: 1. Бібл.: 16.

В статье обоснована необходимость обеспечения основных стейкхолдеров выстего образования объективной информачией о состоянии и развитии региональной высшей школы, что имеет важное значение для обоснования принимаемых управленческих решений. Это требует организации непрерывного мониторинга и прогнозирования изменений региональных рынков образовательных услуг высшего образования. Комплекс исследований должен включать анализ, оценку и прогнозирование процессов, происходящих в высшем образовании региона, а также на рынке труда. Показано, что организация действенного мониторинга возможна лишь при условии тесного взаимодействия региональных высших учебных заведений, органов государственной власти и местного самоуправления. Роль последних состоит в определении направлений развития регионального рынка труда и прогнозировании изменений на нем. На примере Херсонской области показано, что возможной организационной формой, которая позволяет проводить необходимые исследования, может быть научно-исследовательский иентр мониторинга, который создается при органах государственной власти.

Ключевые слова: экономика знаний; человеческий капитал; подготовка кадров; регион; высшее образование; мониторинг высшего образования; прогнозирование высшего образования.

Табл.: 1. Библ.: 16.

The need for appropriate providing the leading stakeholders of higher education with objective information about the local universities' status and development is justified, which is important for making managerial decisions. It requires continuous monitoring and forecasting of the changes at the regional educational services markets in higher education. A complex of studies should include analysis, assessment, and forecasting of processes in higher education of the region, as well as in the labor market. It is shown that effective monitoring is possible only under the condition of close interaction of local higher education institutions, state authorities, and local self-government. The role of the latter is to determine the directions of the regional labor market development and to forecast its changes. On the example of the Kherson region, it is shown that a research and development monitoring center, established by the state authorities, may be a possible organizational form that allows performing the necessary research.

Keywords: knowledge economy; human capital; personnel training; region; higher education; monitoring in higher education; forecasting in higher education.

Table: 1. References: 16.

JEL Classification: I25; J24; J44; O21; P41; R11

Постановка проблеми. Однією з важливих та невирішених проблем вищої освіти $\epsilon$ прогнозування та планування підготовки фахівців. Прогнози та плани повинні хоча б індикативно визначати, фахівці за якими рівнями вищої освіти та спеціальностями і в якій кількості будуть необхідні через певний час. Особливо гострим є регіональний аспект цієї проблеми. Головним виступає завдання забезпечення господарського комплексу кваліфікованими кадрами, компетенції яких відповідають вимогам сучасної еконо-

(C) Ломоносова О. Е., 2019 
міки. Причому ці вимоги невпинно зростають і стрімко змінюються. Не менше значення в цей час має і задоволення потреб населення в освіті безвідносно до потреб регіональної економіки. Водночас нині структури, які б проводили постійне спостереження за розвитком регіональних систем вищої освіти та трансформаціями ринків праці регіонів, складали відповідні прогнози та здійснювали належне регулювання відсутні. У вирішенні цієї проблеми, на наш погляд, головна роль повинна відводитися місцевим органам державної влади та самоврядування.

Аналіз останніх досліджень і публікацій свідчить про постійно зростаючий інтерес закордонних і вітчизняних науковців до питань, що стосуються стану, тенденцій та перспектив розвитку вищої освіти в сучасному світі. Зокрема, ці питання розглядали такі закордонні дослідники, як Л. Бадроуз, Б. Джонстоун, Т. Парсонс, Г. Хаус, М. Фуллан та інші. Значну увагу цій суспільно значущій проблемі надавали у своїх працях вітчизняні науковці В. Андрущенко, М. Згуровський, В. Кремень, І. Мусієнко, С. Ніколаєнко, Т. Оболєнська, В. Парсяк. Питання прогнозування та планування підготовки кадрів із вищою освітою розглядали у своїх працях такі науковці, як Л. Антошкіна, О. Бріт, В. Гапон, О. Григор’єва, Т. Огаренко, В. Сафонова.

Виділення недосліджених частин загальної проблеми. Попри на чисельні публікації дослідників і актуальність розглядуваної проблеми, питання організації прогнозування та планування розвитку регіональних систем вищої освіти, роль органів державної влади й самоврядування в організації забезпечення потреб господарського комплексу регіону в компетентних фахівцях залишаються висвітленою недостатньо.

Мета статті. Завдання статті - сформулювати пропозицій щодо підходів до організації моніторингу регіонального ринку праці та прогнозування майбутніх потреб господарського комплексу регіону в кваліфікованих кадрах.

Виклад основного матеріалу. Економіка регіону є частиною як національної, так i світової економіки. Усі найбільш характерні тенденції розвитку економічних відносин як у всьому світі, так і в окремій країні певною мірою визначають стан і напрями майбутнього розвитку економіки регіону. Це повинно враховуватися місцевими органами державної влади й самоврядування, а також закладами вищої освіти (3ВО) регіону при організації підготовки кадрів для господарського комплексу регіону та регулюванні освітніх процесів.

Результати досліджень закордонних і вітчизняних науковців-економістів свідчать, що об'єктивний і природний процес сучасного розвитку світової економіки характеризується певними особливостями й тенденціями, серед яких найбільш важливими $\epsilon[1$, с. 7$]$ :

- інформатизація суспільних, зокрема економічних відносин;

- пришвидшення темпів науково-технічного прогресу, інноваційного розвитку;

- підвищення ролі інтелектуального капіталу, перехід до економіки знань;

- зростання ролі людського фактору на виробництві, перетворення його творчого потенціалу на основне джерело економічного розвитку;

- глобалізація економічних відносин та зростання ролі уніфікації макро-, мезо- та мікроекономічної політики, здатності фахівців до роботи у відкритому світовому економічному просторі та ін.

Економіка знань, яка породжена загальносвітовим процесом інформатизації та всезростаючими темпами розвитку науки та технологій, вимагає від підприємців зосередження на забезпеченні конкурентоспроможності продукції свого виробництва, передусім, - на виробництві високоякісних знаннємістких товарів і послуг. Нова парадигма економіки передбачає застосування знань власників бізнесу, фахівців, робітників як базового капіталу економічного розвитку, фундаменту конкурентоспроможності на відкритому ринку. 
ПРОБЛЕМИ МЕНЕДЖМЕНТУ ТА РОЗВИТКУ ПРОДУКТИВНИХ СИЛ РЕГІОНУ

Під впливом розвитку господарського комплексу регіону повинно змінюватися співвідношення між екстенсивними та інноваційними галузями (зрозуміло - що на користь інноваційних), високими темпами має відбуватися науково-технічне оновлення та покращення технологічної структури виробництва з активним впровадженням нововведень, раціоналізацією виробництва, зменшенням його ресурсомісткості. Якісні зрушення в господарському комплексі під впливом інноваційних факторів на регіональному ринку праці відбуваються в напрямі збільшення питомої ваги працівників розумової праці, насамперед із вищою освітою, винахідників раціоналізаторів, новаторів виробництва в загальній кількості зайнятих. На регіональному ринку праці зростатиме питома вага працівників інформаційних галузей, висококваліфікованих працівників тощо [1, с. 23].

Характерною особливістю поточного часу є прискорення накопичення суспільством знань і темпів оновлення виробництва. Подвоєння обсягу знань на початку XX сторіччя відбувалося кожні 30 років, у 1970-і роки - кожні 7 років, на початку XXI сторіччя - кожні 5 років [2, с. 30; 3, с. 153]. Це означає, що, по-перше, здобувачі вищої освіти за короткий термін мають опанувати основи обраної професії, підвалини якої були сформульовані впродовж багатьох поколінь теоретиків і практиків. По-друге, випускники ЗВО, які здобули рівень магістра, навчаючись протягом 5 років, практично одразу після закінчення навчання повинні оновлювати свої знання. Крім того, при формуванні креативної економіки дедалі більшого значення має оволодіння студентами надпрофесійних компетенцій, таких як загальна культура, креативність, комунікабельність і здатність до роботи в команді, інноваційність, готовність і здатність вчитися протягом усього життя тощо.

Таким чином, випускники сучасного ЗВО повинні бути готовими працювати в умовах, що диктуватимуться прийдешньою економікою. Вони мають легко та швидко адаптуватися до постійно змінюваних умов. Цим і визначається необхідність змін в організації регіональної системи освіти населення та навчального процесу в закладах освіти.

У ЗВО, наприклад, Херсонської області, відбуваються певні позитивні зміни у сфері підготовки кадрів для майбутньої економіки. Зокрема, уточнюються спеціальності підготовки фахівців, удосконалюються методи викладання дисциплін [4]. Університети переорієнтовуються на новітні форми навчання, методи формування професійних компетентностей випускників. Значного поширення набуває студентоцентрований підхід до навчання, на базі якого у здобувачів вищої освіти формується креативне мислення, критичність та інноваційність, професійна комунікабельність та інші риси, необхідні фахівцю для успішної діяльності у швидко змінюваних та невизначених умовах на різних рівнях господарювання. Подальшого розвитку набуває диверсифікація підготовки фахівців, хоча це і підсилює проблеми, пов'язані зі створенням малокомплектних академічних груп студентів [5].

Ці, а також інші зміни, що відбуваються у ЗВО, є їх реакцією на вплив зовнішнього середовища. Він зумовлений двома групами чинників. Перша - чинники, пов'язані з проблемами вищої освіти України, певна частина яких притаманна також і вищій освіті Європи та США [6, с. 140-142]. Друга група чинників породжена необхідністю задоволення нових вимог до підготовки фахівців, продиктованими сучасним розвитком світової економіки.

Нова економіка потребує і нового розуміння мети, завдання, змісту освіти, у тому числі й вищої. Їх формування відповідно до вимог нової економіки - багатоскладний процес. Проблема полягає в тому, щоб в умовах швидких змін і високих темпів розвитку економіки та суспільства загалом готувати фахівців для майбутньої економіки потрібно вже сьогодні.

Отже, підготовка сучасних фахівців вимагає від 3ВО орієнтації не тільки на поточні, але й на перспективні запити. Тому організація сучасного навчального процесу має будуватися на таких принципах [7]: 
ПРОБЛЕМИ МЕНЕДЖМЕНТУ ТА РОЗВИТКУ ПРОДУКТИВНИХ СИЛ РЕГІОНУ

- єдність освіти з наукою та виробництвом, що є запорукою досягнення мети - підготовки конкурентоспроможного людського капіталу для високотехнологічного та інноваційного розвитку країни, забезпечення потреб суспільства, ринку праці та держави у кваліфікованих фахівцях;

- відповідність знань і вмінь, практичних навичок випускника ЗВО вимогам практичної економіки, що безперервно, високими темпами розвивається;

- відповідність навчального процесу вимогам трансформаційного процесу, що відбувається у вищій школі України;

- заглиблення здобувача вищої освіти в інформаційне поле обраної ним спеціальності та формування його здатності орієнтуватися у фактично безмежному інформаційному полі спеціальності, вести пошук, здійснювати селекцію, відбір актуальної та вивіреної практичної інформації.

Для успішного вирішування завдань, що стоять перед економікою, у тому числі 3 поглядом у майбутнє, слід забезпечувати інтеграцію освіти, науки та бізнесу через встановлення тісної взаємодії місцевих університетів, підприємств, організацій та установ для підготовки кваліфікованих кадрів для виробництва, інтенсифікації трансферу наукових досягнень і спеціальних знань із освітньої та наукової до виробничої сфери. Це передбачає вирішення багатьох завдань із реформування регіональної системи кадрового забезпечення інноваційного розвитку місцевого господарського комплексу. До них, на думку Ж. М. Авілової, належать [8, с. 122-123]:

- випереджальне визначення потреб господарського комплексу в кадрах, компетенції яких відповідатимуть вимогам інноваційної економіки, економіки знань;

- створення умов для залучення кадрових ресурсів у регіональну інноваційну систему та формування стійких зовнішніх зв'язків, що забезпечили б участь фахівців в управлінні інноваційною діяльністю регіону;

- якісне оновлення структури, змісту і технологій професійної освіти;

- розвиток системи перенавчання працівників, що вивільнені, а також незайнятого населення.

До цього слід також додати:

- формування стабільних довготривалих відносин між суб'єктами освітньої та виробничої сфер, які б забезпечували конкурентоспроможність підприємств;

- створення передумов для комерціалізації наукових досягнень і тим самим - фундаменту для самофінансування інноваційної, науково-технічної та винахідницької діяльності;

- структурну перебудову, що передбачає підвищення частки наукомістких, високотехнологічних галузей, а також видів діяльності, які стимулюють їхній розвиток;

- навчання керівних кадрів, фахівців, бізнесменів сучасним методам управління інтелектуальним капіталом підприємств.

Складним і відповідальним завданням $є$ визначення вектора розвитку регіональних ЗВО. Це пояснюється тим, що економіка регіону при формуванні кадрового потенціалу в сучасних умовах може розраховувати тільки на свої власні можливості. Фахівці за всіма необхідними спеціальностями сьогодні можуть бути підготовлені лише в місцевих 3ВО. 3 тих абітурієнтів, що виїжджають на навчання до інших, здебільшого великих міст України та за кордон, назад повертаються одиниці, а запрошувати фахівців 3 інших регіонів досить складно або взагалі неможливо. Крім того, досить часто відсутні зрозумілі орієнтири розвитку регіональної економіки. Це ще більше ускладнює підготовку фахівців, які будуть затребувані через чотири або п'ять років.

Для успішного вирішення завдань, що стоять перед регіональною економікою, зокрема 3 поглядом у майбутнє, налагодження ефективного регулювання регіональних систем вищої освіти, насамперед необхідно забезпечити підприємства, організації, урядо- 
ві установи, громадськість, а також інших користувачів об'єктивною інформацією щодо стану та розвитку вищої школи. Повна, своєчасна та достовірна інформація про стан і розвиток місцевих ЗВО, зміни в уподобанні споживачів освітніх послуг вищої освіти, очікувану чисельність фахівців з вищою освітою за різними спеціальностями та освітніми програмами в наступні роки повинна відігравати важливу й навіть вирішальну роль при обгрунтуванні управлінських рішень, пов'язаних із вищою освітою.

Отримання необхідної інформації вимагає організації безперервного моніторингу регіональних ринків освітніх послуг вищої освіти. Такий моніторинг має забезпечувати аналіз стану справ у регіональній системі вищої освіти, давати змогу швидко і правильно оцінювати процеси, що відбуваються, прогнозувати зміни та своєчасне вносити необхідні корективи в діяльність навчальних закладів, визначати пріоритети в їхньому розвитку, фінансуванні тощо [9, с. 114]. Обов'язковим є виконання комплексу досліджень, які включають аналіз, оцінку, а також прогнозування процесів, що відбуваються у вищій освіті регіону та на ринку праці.

Це дасть можливість підвищити рівень якості інформації, що отримують користувачі, більшою мірою задовольняти їхні потреби за рахунок надання не просто інформації, а підсумків аналізу та результатів прогнозу. Своєчасне передбачення необхідності змін у підготовці фахівців має сприяти значному підвищенню ефективності регіональних систем вищої освіти.

Результати регіонального моніторингу можуть використовуватися при формуванні концепцій, програм і планів розвитку вищої освіти, контролі реалізації державної політики у сфері вищої освіти регіону, вирішенні питань оптимізації мережі ЗВО та їхніх відокремлених структурних підрозділів, проведення експертного оцінювання доцільності створення в регіоні нових ЗВО, внесенні до Міністерства освіти і науки України пропозицій, спрямованих на поліпшення функціонування ЗВО регіону.

Не менш важливим $є$ моніторинг регіональних ринків праці. ЗВО, незважаючи на досвід багаторічного вирішення проблем із формуванням контингенту здобувачів вищої освіти і наявність певних напрацювань із визначення освітянських потреб підприємств та населення, самостійно не в змозі проводити глибокий аналіз потреб регіонального ринку освітніх послуг, здійснювати чіткий прогноз потреб місцевого господарського комплексу у фахівцях відповідних рівнів вищої освіти та спеціальностей. I причина цьому не у непрофесійності організаторів підготовки фахівців, а у складності прогнозування підготовки фахівців в умовах значної невизначеності інформації про напрями розвитку регіонів, що додатково ускладнюється нестабільністю зовнішнього середовища. Так, на Херсонщині відповідь на питання про перспективну потребу у фахівцях з вищою освітою не дає і стратегія економічного й соціального розвитку регіону [10], яка неузгоджена з прогнозами та планами розвитку галузей і підприємств. Ще одна причина полягає у слабкій обізнаності ЗВО про діяльність місцевих органів влади та місцевого самоврядування. У більшості випадків відсутні належні зв'язки університетів із регіональними центрами зайнятості, які формують свої плани та прогнози, з управлінням праці та зайнятості населення Департаменту соціального захисту населення тощо.

На жаль, проблема узгодження ринку праці та ринку освітніх послуг в Україні не вирішена. Ще у 2004 році Міністерством праці та соціальної політики, Міністерством освіти і науки України, Національною академією наук України та Науково-дослідним інститутом праці та зайнятості населення були розроблені «Методичні рекомендації щодо визначення потреби у фахівцях 3 повною вищою освітою» [11]. Науково-дослідним інститутом соціально-трудових відносин Міністерства соціальної політики України були розроблені «Методичні рекомендації щодо визначення відповідності обсягів та професійно-кваліфікаційної структури підготовки кадрів у навчальних закладах відповідно до потреб регіонального ринку праці» [12]. На жаль, ці рекомендації не були реалізовані. У цей час вони потребують суттєвого удосконалення з урахуванням вимог сьогодення. 
ПРОБЛЕМИ МЕНЕДЖМЕНТУ ТА РОЗВИТКУ ПРОДУКТИВНИХ СИЛ РЕГІОНУ

Водночас у світі багато країн накопичили певний досвід підготовки фахівців відповідно до потреб національної економіки. При цьому дослідженням, прогнозуванням і плануванням національних та регіональних ринків освітніх послуг і ринків праці займаються державні органи, організації роботодавців, представники університетів (таблиця).

Таблиця

Організація визначення потреб у фахівиях у деяких країнах світу

\begin{tabular}{|c|c|c|}
\hline Країна & $\begin{array}{l}\text { Орган, що відповідас за про- } \\
\text { гнозування або планування }\end{array}$ & $\begin{array}{c}\text { Питання, що досліджуються, та процеси і } \\
\text { показники, які прогнозуються або плануються }\end{array}$ \\
\hline 1 & 2 & 3 \\
\hline $\begin{array}{l}\text { 1. Великобри- } \\
\text { танія }\end{array}$ & $\begin{array}{l}\text { Інститут досліджень } \\
\text { зайнятості }\end{array}$ & $\begin{array}{l}\text { 1. Попит на фахівців } \\
\text { 2. Прогнози: } \\
\text { - зміни структури галузей економіки; } \\
\text { - зміни зайнятості в економіці; } \\
\text { - розподілу зайнятості за професіями і типом зайнятості; } \\
\text { - пропозиції на кваліфікованому ринку праці. } \\
\text { Термін прогнозування становить 5-10 років, оновлен- } \\
\text { ня здійснюється кожного року }\end{array}$ \\
\hline \multirow{3}{*}{ 2. Німеччина } & $\begin{array}{l}\text { 1. Інститут досліджень } \\
\text { економічної структури }\end{array}$ & $\begin{array}{l}\text { 1. Дослідження зміни структури економіки } \\
\text { 2. Прогнози: } \\
\text { - зайнятості; } \\
\text { - прогноз у розрізі професій і кваліфікацій (рівень } \\
\text { компетенції); } \\
\text { - пропозицій на ринку праці }\end{array}$ \\
\hline & $\begin{array}{l}\text { 2. Інститут дослідження } \\
\text { зайнятості }\end{array}$ & $\begin{array}{l}\text { 1. Розробка прогнозу попиту на робочу силу й прогно- } \\
\text { зу пропозиції робочої сили } \\
\text { 2. Прогнози: } \\
\text { - загального економічного зростання і змін в економі- } \\
\text { ці в розрізі зайнятості за } 22 \text { галузями економіки; } \\
\text { - зміни структури професійної зайнятості в кожній із } \\
22 \text { галузей економіки для } 21 \text { групи професій }\end{array}$ \\
\hline & $\begin{array}{l}\text { 3. Федеральне міністерство } \\
\text { освіти й науки } \\
\text { 4. Проєктне агентство з питань } \\
\text { праці й технологій } \\
\text { 5. Федеральний інститут про- } \\
\text { фесійної освіти та навчання; } \\
\text { 6. Інститут досліджень } 3 \text { пи- } \\
\text { тань ринку праці та професій } \\
\text { при Федеральному інституті } \\
\text { зайнятості та інші структури } \\
\end{array}$ & Дослідженням змін у професіях і вміннях \\
\hline \multirow{3}{*}{ 3. Франція } & $\begin{array}{l}\text { 1. Міжнародне бюро економі- } \\
\text { чних перспектив }\end{array}$ & Макроекономічні прогнози \\
\hline & $\begin{array}{l}\text { 2. Регіональні міжгалузеві } \\
\text { комісії з питань зайнятості }\end{array}$ & Регіональні прогнози \\
\hline & 3. Галузеві обсерваторії & $\begin{array}{l}\text { Регіональні прогнози, які використовуються регіона- } \\
\text { льними органами влади і структурами для розробки } \\
\text { нових траєкторій навчання й закриття курсів, які не } \\
\text { відповідають сучасним потребам }\end{array}$ \\
\hline 4. Бельгія & $\begin{array}{l}\text { Програма стратегічних } \\
\text { досліджень ринку праці } \\
\text { (у межах угоди між урядом і } \\
\text { соціальними партнерами) }\end{array}$ & $\begin{array}{l}\text { 1. Здійснюється опитування експертів } \\
\text { 2. Проводяться конференції представників галу- } \\
\text { зей/секторів економіки для обговорення проєкту до- } \\
\text { кумента та заключна конференція за участю представ- } \\
\text { ників освітніх установ. } \\
\text { 3. Затверджуються профілі професій, які використо- } \\
\text { вуються для розробки стандартів. } \\
\text { Щорічно готується звіти про економічну й соціальну } \\
\text { ситуацію в країні, описання конкретної професії або } \\
\text { групи професій }\end{array}$ \\
\hline
\end{tabular}


Закінчення табл.

\begin{tabular}{|c|c|c|}
\hline 1 & 2 & 3 \\
\hline \multirow{8}{*}{ 5. Данія } & 1. Міністерство праці & Пропозиції на ринку праці \\
\hline & $\begin{array}{l}\text { 2. Міністерство бізнесу та } \\
\text { промисловості }\end{array}$ & Тенденції та потреби з погляду попиту на ринку праці \\
\hline & $\begin{array}{l}\text { 3. Данський технологічний } \\
\text { інститут }\end{array}$ & $\begin{array}{l}\text { Зміни ситуації у: } \\
\text { - сфері зайнятості; } \\
\text { - затребуваності професій; } \\
\text { - професійному навчанні }\end{array}$ \\
\hline & 4. Данська економічна рада & $\begin{array}{l}\text { 1. Комплексний аналіз економіки } \\
\text { 2. Зміна структури заробітної плати тощо }\end{array}$ \\
\hline & $\begin{array}{l}\text { 5. Центральне статистичне } \\
\text { бюро Данії }\end{array}$ & \multirow{3}{*}{ Проблеми моніторингу та прогнозів } \\
\hline & $\begin{array}{l}\text { 6. Економічна рада з питань } \\
\text { робочого руху }\end{array}$ & \\
\hline & $\begin{array}{l}\text { 7. Заклади вищої освіти, } \\
\text { соціальні партнери }\end{array}$ & \\
\hline & $\begin{array}{l}\text { 8. Регіональні ради з питань } \\
\text { ринку праці }\end{array}$ & $\begin{array}{l}\text { 1. Вивчення попиту та пропозиції робочої сили } \\
\text { 2. Аналіз рівня освіти та зайнятості потенційних працівників } \\
\text { 3. Моніторинг і прогнозування потреби в уміннях та компе- } \\
\text { тенціях; }\end{array}$ \\
\hline 6. Ірландія & $\begin{array}{l}\text { Експертна група з вивчення } \\
\text { перспективного попиту на } \\
\text { професійні навички }\end{array}$ & $\begin{array}{l}\text { 1. Аналіз попиту на професії } \\
\text { 2. Розробка пропозицій щодо задоволення попиту на профе- } \\
\text { сії за участю широкого кола учасників, включаючи предста- } \\
\text { вників бізнесу, сфери освіти, профспілок, а також держави } \\
\text { 3. Визначення основних елементів майбутнього портфелю } \\
\text { типових професійних навичок } \\
\text { 4. Надання рекомендацій з підвищення рівня поінформова- } \\
\text { ності здобувачів роботи про галузі, в яких є попит на відпо- } \\
\text { відні професійні навички }\end{array}$ \\
\hline \multirow[b]{2}{*}{ 7. США } & $\begin{array}{l}\text { 1. Агентство трудової } \\
\text { статистики }\end{array}$ & $\begin{array}{l}\text { Дослідження потреб економіки у кваліфікованих кадрах } \\
\text { шляхом: } \\
\text { - моделювання; } \\
\text { - переговорів і опитувань представників промисловості, при- } \\
\text { ватних організацій, професійних і торговельних об’єднань, } \\
\text { експертів з підготовки кадрів та працівників освіти }\end{array}$ \\
\hline & 2. Департамент праці & $\begin{array}{l}\text { 1. Прогнозування: } \\
\text { - стану ринку робочої сили; } \\
\text { - макроекономічних показників; } \\
\text { - особистого споживання; } \\
\text { - економічної активності; } \\
\text { - зайнятості у галузях економіки; } \\
\text { - сукупної зайнятості за видами економічної діяльності }\end{array}$ \\
\hline 8. Канада & $\begin{array}{l}\text { Канадська служба } 3 \\
\text { розвитку людських ресурсів } \\
\text { i професійних навичок }\end{array}$ & $\begin{array}{l}\text { Надає учням, працівникам і роботодавцям інформацію про } \\
\text { перспективні потреби в професійних навичках }\end{array}$ \\
\hline
\end{tabular}

Джерело: складено автором на основі [13].

Для України принциповим $є$ початковий етап координуючої роботи місцевих органів державної влади і місцевого самоврядування, а саме - випереджальне визначення потреб господарського комплексу регіону в кадрах, компетенції яких відповідають вимогам нової економіки. Організація моніторингу повинна будуватися на взаємодії місцевих 3ВО, органів державної влади та місцевого самоврядування. Роль останніх полягає, передусім, у визначенні напрямів розвитку, своєчасному внесенню необхідних відповідних коректив і прогнозуванні ситуації на регіональному ринку праці. Це дасть змогу забезпечувати адекватність регіонального ринку освітніх послуг потребам ринку праці з урахуванням перспектив соціально-економічного розвитку регіону, задовольняти потреби регіону у фахівцях із вищою освітою за необхідними рівнями та спеціальностей. 
ПРОБЛЕМИ МЕНЕДЖМЕНТУ ТА РОЗВИТКУ ПРОДУКТИВНИХ СИЛ РЕГІОНУ

Як організаційну форму для проведення безперервного моніторингу регіональних систем вищої освіти доцільно використовувати науково-дослідні центри моніторингу, створювані при органах державної влади. Саме такий центр у 2017 році організований при Херсонській обласній адміністрації. Він є громадською організацією при голові Херсонської обласної державної адміністрації, яка здійснює дослідження стану та розвитку вищої освіти області. Метою функціонування цього центру є здійснення моніторингу та проведення системних досліджень у сфері вищої освіти, також у суміжних із нею галузях, з питань, які пов'язані з підготовкою та перепідготовкою фахівців.

Науково-дослідний центр моніторингу регіональної вищої освіти при Херсонській обласній адміністрації створений на базі наукової лабораторії економічних проблем вищої освіти Херсонської філії Національного університету кораблебудування, яка має великий досвід дослідження регіональної вищої освіти. Фахівцями лабораторії сформована потужна інформаційна база даних щодо стану та розвитку вищої освіти в Херсонській області та Україні загалом, яка використовується в роботі центру. До складу центру увійшли представники Херсонської обласної адміністрації та провідні науковці Херсонської філії Національного університету кораблебудування.

Важливим є співробітництво між такими центрами та іншими організаціями, що займаються освітньою та інноваційною діяльністю. Так, у разі наявності в регіоні освітніх або інноваційних кластерів, наприклад, таких як у Чернігові [14], між ними та центрами моніторингу має бути налагоджена тісна взаємодія.

Напрацювання Науково-дослідного центру моніторингу регіональної вищої освіти при Херсонській обласній адміністрації були використані при підготовці обласної програми «Розвиток людського капіталу Херсонської області» на 2017-2023 роки [15]. Ця програма передбачає проведення регулярного моніторингу регіонального ринку праці та визначення потреб у фахівцях із вищою освітою. На основі дослідження формується регіональне замовлення на підготовку фахівців за дефіцитними спеціальностями. Так, у 2017 році до замовлення було включено завдання на підготовку 33 фахівців, у тому числі 21 педагога, 7 медичних працівників, 2 працівників культури і 3 фахівців агропромислового комплексу. Програмою передбачено надання молоді пільгових кредитів на здобуття вищої освіти.

Треба зазначити, що заходи програми, попри свою актуальність, мають дещо звужену спрямованість. Моніторинг регіонального ринку праці проводиться переважно в галузях бюджетної сфери, регіональне замовлення на підготовку фахівців за дефіцитними спеціальностями також здійснюється за цими галузями.

Система регіонального замовлення на підготовку кадрів потребує свого розширення. Насамперед необхідно збільшити перелік спеціальностей та освітніх програм, за якими формується регіональне замовлення. При цьому доцільно передбачити формування місцевими громадами переліків гостродефіцитних спеціальностей та спеціалізацій, які зможуть включатися до регіонального замовлення об'єднаних територіальних громад, органів місцевого самоврядування всіх рівнів на підготовку кадрів згідно з місцевими потребами і за кошти місцевих бюджетів.

Зважаючи на те, що державне замовлення є засобом державного регулювання задоволення потреб суспільства загалом, економіки та регіональних соціально-економічних систем у кваліфікованих кадрах [16], у державному замовленні необхідно передбачати замовлення регіону на підготовку кадрів для замовлення регіону на підготовку кадрів для місцевого господарського комплексу, яке має фінансуватися 3 державного бюджету й виконуватися 3ВО, розташованими в цьому регіоні.

Визначення та задоволення потреб Херсонської області у фахівцях із вищою освітою не тільки за вказаними, а за усіма пріоритетними спеціальностями та спеціалізаціями, є необхідним для забезпечення гармонійного розвитку регіону. Це, у свою чергу, 
ПРОБЛЕМИ МЕНЕДЖМЕНТУ ТА РОЗВИТКУ ПРОДУКТИВНИХ СИЛ РЕГІОНУ

передбачає постійне відслідковування відповідності регіонального ринку освітніх послуг потребам ринку праці з урахуванням перспектив соціально-економічного розвитку регіону і внесення відповідних змін в Обласну програму «Розвиток людського капіталу Херсонської області» на 2017-2023 роки.

3 метою попередження асиметрії в забезпеченні професійними кадрами регіональних господарських комплексів необхідно також внести деякі зміни до порядку планування підготовки кадрів у регіональних 3ВО. Їхні плани набору абітурієнтів повинні враховувати показники планів Міністерства освіти і науки України, рекомендації регіональних програм розвитку вищої освіти і розроблятися на основі власних досліджень регіонального, всеукраїнського ринку освітніх послуг, з урахуванням прогнозів майбутніх потреб у фахівцях, розроблених місцевими органами державної влади й місцевого самоврядування, а також попиту на освітні послуги місцевого населення, роботодавців. Плани мають формуватися з урахуванням місцевих обсягів підготовки фахівців і результатів акредитації закладу вищої освіти. Важливим розділом плану має бути завдання з підготовки науково-педагогічних працівників, забезпечення якості освіти.

Висновки та пропозиції. Наведені вище пропозиції - це лише невідкладні, першочергові заходи, яких необхідно вжити місцевим органам державної влади і самоврядування, ЗВО для забезпечення не тільки поточного попиту населення у вищій освіті і підприємств регіонального господарського комплексу у фахівцях, а i для підготовки спеціалістів, компетентності яких відповідатимуть вимогам економіки завтрашнього дня. Відповідні доповнення доцільно внести й у обласну програму «Розвиток людського капіталу Херсонської області».

Досвід Херсонської області зі створення Науково-дослідного центру моніторингу регіональної вищої освіти при Херсонській обласній адміністрації може використовуватися місцевими органами влади інших регіонів України. Актуальним питанням залишається розробка методики стратегічного прогнозування потреб регіонів у фахівцях 3 вищою освітою. Подальших досліджень вимагають також питання формування державного замовлення на підготовку кадрів з урахуванням замовлень регіону.

\section{Список використаних джерел}

1. Вища освіта, наука, виробництво: теорія і практика інтеграції у сфері фінансів: монографія / за. ред. М. А. Коваленка. Херсон: ХНТУ, 2015. 172 с.

2. Bontis N. CKO Wanted - Evangelical Skills Necessary: A review of the Chief Knowledge Officer position. Knowledge and Process Management. 2001. Vol. 8, № 1. P. 29-38.

3. Людський розвиток в Україні: можливості та напрями соціальних інвестицій / за ред. Е. М. Лібанової. Київ: Ін-т демографії і соц. дослідж. НАН України, 2006. 300 с.

4. Коваленко М. А., Ломоносова О. Е., Швороб Е. О. Методи викладання економіки у сучасній вищій школі: науково-методичний посібник. Херсон: Олді-плюс, 2019. 220 с.

5. Lomonosova O. E., Lomonosov A.V., Boiko L. M. Research on the processes of reducing the number of students of one speciality at the higher technical institutions in Ukraine. Вісник Хмельнииького національного університету. Економічні науки : збірник наукових праць. 2016. Т. 1 (238), № 4. C. 91-95.

6. Lomonosov A., Lomonosova O., Nadtochii I. The systematization and classification of socioeconomic problems in higher education. Baltic Journal of Economic Studies. Riga: Publishing House «Baltija Publishing». 2019. Vol. 5 (2019), № 4. P. 137-148.

7. Коваленко М. А., Ломоносов А. В., Ломоносова О. Е., Житченко Е. О. Інтелектуальний капітал підприємства. Херсон: Олді-плюс, 2019. 456 с.

8. Авилова Ж. Н. Роль ВУЗа в процессе воспроизводства интеллектуального капитала региона. Воспроизводство интеллектуального капитала в системе высшего профессионального образования: материалы Всерос. науч.-практ. конф. с межд. уч., 18-22 ноября 2013 г. Белгород: НИУ «БелГУ», 2013. С. 122-127. 
ПРОБЛЕМИ МЕНЕДЖМЕНТУ ТА РОЗВИТКУ ПРОДУКТИВНИХ СИЛ РЕГІОНУ

9. Університетський менеджмент: актуальні аспекти: монографічна серія / Вербовська О. Г., Ломоносова О. Е. та ін.; за ред. В. Н. Парсяка. Херсон: Видавничий дім «Гельветика», 2018. 296 с.

10. Стратегія розвитку Херсонської області на період до 2020 року: затверджено рішенням XXXVI сесії Херсонської обласної ради VI скликання від 10 вересня 2015 року № 1296. URL: https://khoda.gov.ua/strategiya-rozvitku-2020.

11. Методичні рекомендації щодо визначення потреб у фахівцях із повною вищою освітою: практично-методичне видання / уклад.: НДІ праці і зайнятості населення Мінпраці та НАН України. Київ: Спецінфрм, 2004. 43 с.

12. Методичні рекомендації щодо визначення відповідності обсягів та професійнокваліфікаційної структури підготовки кадрів у навчальних закладах відповідно до потреб регіонального ринку праці. Луганськ: Видавництво ДУ НДІ СТВ, 2010. 37 с.

13. Карпенко М. М. Свропейський досвід планування підготовки вищими навчальними закладами затребуваних спеціалістів: аналітична записка. URL: https:/niss.gov.ua/doslidzhennya/ gumanitarniy-rozvitok/evropeyskiy-dosvid-planuvannya-pidgotovki-vischimi-navchalnimi.

14. Лисенко І. В. Механізм взаємодії регіональних інноваційних кластерів та вищої освіти. Проблеми і перспективи економіки та управління. 2019. № 1 (17). С. 143-154.

15. Обласна програма «Розвиток людського капіталу Херсонської області»: затверджено рішенням XII сесії обласної ради VI скликання від 10 квітня 2017 року № 473. URL: http://khor.gov.ua/wp-content/uploads/2017/04/ rish12ses7scl/473.pdf.

16. Чумакова І. Ю., Кравченко Ю. П. Освітні послуги закладів вищої освіти в межах державного замовлення як об'єкт внутрішнього контролю. Проблеми і перспективи економіки та управління. 2018. № 2 (14). С. 32-40.

\section{References}

1. Kovalenko, M. A. (Ed.). (2015). Vyshcha osvita, nauka, vyrobnytstvo: teoriia i praktyka intehratsii u sferi finansiv [Higher Education, Science, Production: Theory and Practice of the Integration in Finance]. Kherson: KhNTU [in Ukrainian].

2. Bontis, N. (2001). CKO Wanted - Evangelical Skills Necessary: A review of the Chief Knowledge Officer position. Knowledge and Process Management, 8 (1), 29-38.

3. Libanova, E. M. (2006). Liudskyi rozvytok v Ukraini: mozhlyvosti ta napriamy sotsialnykh investytsii [Human development in Ukraine: opportunities and directions of social investment]. Kyiv: In-t demohrafii i sots. doslidzh. NAN Ukrainy [in Ukrainian].

4. Kovalenko, M. A., Lomonosova, O. E., Shvorob, E. O. (2019). Metody vykladannia ekonomiky u suchasnii vyshchii shkoli [Methods of teaching economics in modern higher education]. Kherson: Oldi-plius [in Ukrainian].

5. Lomonosova, O. E., Lomonosov, A. V., Boiko, L. M. (2016). Research on the processes of reducing the number of students of one speciality at the higher technical institutions in Ukraine [Research on the processes of reducing the number of students of one specialty at higher technical institutions in Ukraine]. Visnyk Khmelnytskoho natsionalnoho universytetu. Ekonomichni nauky Bulletin of Khmelnitsky National University. Economic sciences, 4 (1 (238)), 91-95 [in Ukrainian].

6. Lomonosov, A., Lomonosova, O., Nadtochii, I. (2019). The systematization and classification of socio-economic problems in higher education. Baltic Journal of Economic Studies, 5 (4), $137-148$. Riga: Publishing House «Baltija Publishing».

7. Kovalenko, M. A., Lomonosov, A. V., Lomonosova, O. E., Zhytchenko, E. O. (2019). Intelektualnyi kapital pidpryiemstva [Intellectual capital of the enterprise]. Kherson: Oldi-plius [in Ukrainian].

8. Avilova, Zh. N. (2013). Rol VUZa v proczesse vosproizvodstva intellektual nogo kapitala regiona [The role of universities in the process of the reproduction of intellectual capital of the region]. Proceeding from Vosproizvodstvo intellektualnogo kapitala v sisteme vysshego professionalnogo obrazovaniia: materialy Vseros. nauch.-prakt. konf. - Reproduction of intellectual capital in higher education: materials of All-Russian Research-to-Practice Conference (November 18-22, 2013). (pp. 122-127). Belgorod: NIU «BelGU» [in Russian].

9. Verbovska, O. H., Lomonosova, O. E., Parsiaka, V. N. (Ed.). (2018). Universytetskyi menedzhment: aktualni aspekty: monohrafichna seriia [University management: topical aspects: a monographic series]. Kherson: Vydavnychyi dim «Helvetyka» [Ukrainian]. 
ПРОБЛЕМИ МЕНЕДЖМЕНТУ ТА РОЗВИТКУ ПРОДУКТИВНИХ СИЛ РЕГІОНУ

10. Stratehiia rozvytku Khersonskoi oblasti na period do 2020 roku [Strategy of the development of Kherson region for the period up to 2020]. № 1296 (10.09.2015). Retrieved from https://khoda.gov.ua/strategiya-rozvitku-2020.

11. NDI pratsi i zainiatosti naselennia Minpratsi ta NAN Ukrainy [Research Institute of Labor and Employment of the Ministry of Labor and National Academy of Sciences of Ukraine]. (2004). Metodychni rekomendatsii shchodo vyznachennia potreb u fakhivtsiakh iz povnoiu vyshchoiu osvitoiu [Methodical recommendations for determining the needs of specialists with full higher education]. Kyiv: Spetsinfrm [Ukrainian].

12. Metodychni rekomendatsii shchodo vyznachennia vidpovidnosti obsiahiv ta profesiinokvalifikatsiinoi struktury pidhotovky kadriv u navchalnykh zakladakh vidpovidno do potreb rehionalnoho rynku pratsi [Methodical recommendations for determining the correspondence of volumes and vocational qualification structure of training in educational institutions in accordance with the needs of the regional labor market] (2010). Luhansk: Vydavnytstvo DU NDI STV [Ukrainian].

13. Karpenko, M. M. (n.d.). Yevropeiskyi dosvid planuvannia pidhotovky vyshchymy navchalnymy zakladamy zatrebuvanykh spetsialistiv: analitychna zapyska [The European experience of planning the training of specialists in demand by higher education institutions: an analytical note]. Retrieved from https://niss.gov.ua/doslidzhennya/gumanitarniy-rozvitok/evropeyskiy-dosvid-planuvannyapidgotovki-vischimi- navchalnimi.

14. Lysenko, I. V. (2019). Mekhanizm vzaiemodii rehionalnykh innovatsiinykh klasteriv ta vyshchoi osvity [Interaction mechanism of regional innovative clusters and higher education]. Problemy $i$ perspektyvy ekonomiky ta upravlinnia - Problems and prospects of economics and management, 1 (17), 143-154 [Ukrainian].

15. Oblasna prohrama «Rozvytok liudskoho kapitalu Khersonskoi oblasti» [Regional Program «Human Capital Development in Kherson Region»]. № 473 (10.04.2017). Retrieved from http://khor.gov.ua/wp-content/uploads/2017/04/ rish12ses7scl/473.pdf.

16. Chumakova, I. Yu., Kravchenko, Yu. P. (2018). Osvitni posluhy zakladiv vyshchoi osvity v mezhakh derzhavnoho zamovlennia yak obiekt vnutrishnoho kontroliu [Educational services of institutions of higher education in the framework of the state order as object of internal control]. Problemy i perspektyvy ekonomiky ta upravlinnia - Problems and prospects of economics and management, 2 (14), 32-40. [Ukrainian].

Ломоносова Оксана Едуардівна - кандидат економічних наук, доцент, завідувачка кафедри економіки, Херсонська філія Національного університету кораблебудування імені адмірала Макарова (просп. Ушакова, 44, м. Херсон, 73000, Україна).

Ломоносова Оксана Эдуардовна - кандидат экономических наук, доцент, заведующая кафедрой экономики, Херсонский филиал Национального университета кораблестроения имени адмирала Макарова (пр. Ушакова, 44, г. Херсон, 73000, Украина).

Lomonosova Oksana - PhD in Economics, Associate Professor, Head of the Chair of Economics, Admiral Makarov National University of Shipbuilding, Kherson Branch (44 Ushakov Av., 73000 Kherson, Ukraine).

E-mail: alvirginis@gmail.com

ORCID: https://orcid.org/0000-0002-1007-3786

ResearcherID: V-4858-2017 